\title{
A genetic and biochemical study of obesity in Egypt
}

\author{
Noha Mohamed Said ${ }^{1}$, Fathy yassin ${ }^{2}$, and Sara Selim ${ }^{1}$ \\ ${ }^{1}$ Biochemistry Division, Chemistry Department, Faculty of science, Zagazig University, \\ Zagazig, Egypt \\ ${ }^{2}$ Chemistry Department, Faculty of science, Zagazig University, Zagazig, Egypt
}

\begin{tabular}{l}
\hline A R T I C L E I N F O \\
\hline Obesity, BMI, Adiponectin \\
gene polymorphism, biomarker
\end{tabular}

gene polymorphism, biomarker
A B S T R A C T

Background: Numerous studies have documented the association adiponectin (ADIPOQ) gene polymorphisms with obesity but the consequences are indecisive. The purpose of this work is to study the connection between adiponectin gene polymorphisms G276T and T45G with obesity and biochemical variants in Egyptian population. Material and methods: Genotyping of G276T single nucleotide polymorphisms of adiponectin gene was performed by Alleles Refractory Mutation Systems PCR(ARMS PCR) method, while Genotyping of T45G single nucleotide polymorphism of adiponectin gene was performed by RFLP PCR method. The analysis was done in 172 matched person; 89 obese patients, 43 overweight patients, and 40 normal healthy controls. Biochemical parameters were calculated through standard procedures. Results: For adiponectin polymorphism G276T, it was related to overweight under Co dominant and recessive models $(\mathrm{P}=0.010, \mathrm{P}=0.036)$ respectively, also it was associated with obesity under recessive model $(\mathrm{P}=0.048)$. Higher BMI was associated with heterozygous GT and homozygous GG carriers of G276T $(\mathrm{P}=0.032)$ compared to TT carriers, For adiponectin gene polymorphism T45 $\mathrm{G}$, it was associated with Obesity under Co dominant and dominance models $(\mathrm{P}=0.046, \mathrm{P}=0.045)$ respectively. Heterozygous GT and homozygous GG carriers of T45G were related higher $\mathrm{BMI}(\mathrm{P}=0.029)$, triglyceride $(\mathrm{P}=$ $0.029)$, and VLDL $(\mathrm{P}=0.026)$ compared to TT carriers at adiponectin polymorphism T45G. Conclusion: The study suggests that the ADIPOQ 276G $>$ T and ADIPOQ 45T $>\mathrm{G}$ polymorphisms may be vital indicators of obesity and associated complications in several population.

(C) 2017 Publisher All rights reserved. 


\section{INTRODUCTION}

Obesity is a great problem all over the world. it is considered a health problem. Obesity increases the risk of many common diseases, including coronary artery disease (CAD), type 2 diabetes mellitus (DM), high blood pressure, gallbladder disease, and osteoporosis $^{(1)}$. As a result, obesity increases mortality ${ }^{(2,3)}$. Obesity has become a widspread epidemic (4,5). Participants rated they were obese if their BMI was greater than or equal to $30 \mathrm{~kg} / \mathrm{m}^{2}{ }^{(6)}$. Body mass index (BMI) was calculated by dividing the weight in kilograms per square meter in meters by approximating the results to the nearest decimal number, overweight if BMI was 25 to 29.9 and obesity if BMI was 30.0 and above, and obesity was splitted into grade 1 (BMI 30-35), grade 2 (BMI 35-40), and grade $3(\text { BMI } \geq 40)^{(7)}$. The causes of obesity are multiple genetic, environmental, socioeconomic or psychological effects with increasing rates of illness and death ${ }^{(8)}$. Obesity is the end result of a chronic energy imbalance and is regulated by a multifarious network between the endocrine and central nervous system $(9,10)$. Fatty tissue was considered as an energetic endocrine system with high metabolic activity. Adipocytes produce and secrete several proteins that act as veritable hormones and are responsible for regulating energy consumption and expenditure ${ }^{(11)}$. Many of these hormones are called adipokines, which play important roles in inflammatory and arteriosclerosis processes. These comprise of tumor necrosis factor (TNF) $\alpha$, leptin , interleukin (IL) 6 , angiotensinogen, and plasminogen activator inhibitor-1. Increasing sign shows that adiposity participates in a proinflammatory milieu ${ }^{(12)}$. Reduction in fat bulk associated with decrease in the serum levels of many of these proinflammatory adipokines which mean that approaches designed to promote fat loss should be useful in attenuating the proinflammatory environment associated with obesity ${ }^{(12)}$. Adiponectin has recently been described as secretory product of adipose tissue (13). Adiponectin is a relatively plentiful serum protein secreted by adipocytes ${ }^{(14)}$. Some studies have showen that level of adiponectin is related with insulin resistance (15), and with glucose and lipid metabolism $^{(16)}$. According to reports, adiponectin wasn't association with metabolic syndrome $(\mathrm{MS})^{(17,18)}$.The ADIPOQ gene consists of three exons and two introns spanning a $17-\mathrm{kb}$ region and located on chromosome $3 \mathrm{q} 27^{(19)}$. It has been reported that genetic variants in the gene encoding adiponectin (ADIPOQ) are associated with the level of adiponectin in several genome-wide linkage and association studies $(20,21)$ Several polymorphisms within adiponectin gene have been identified ${ }^{(23)}$.

\section{SUBJECTS AND METHODS}

\section{SUBJECTS AND METHODS Study Design and Participants}

An observational case-control study was conducted between March, 2013 to October,2013. The study was approved by the Faculty of science, Zagazig University, and analyze labs. This case_control study included 172 age and sex matched person, The age of the patients ranged from 15-55 years. They were 89 obese patients, 43 overweight patients, and 40 normal health controls. For all subjects, body weight and height were measured ; Body mass index (BMI) was computed as weight $(\mathrm{kg})$ divided by height squared $\left(\mathrm{m}^{2}\right)$. Blood pressure was measured three times and the mean was taken for analysis.

\section{Blood Sampling and biochemical Measurements}

Taking $5 \mathrm{ml}$ of blood from each person, 2 $\mathrm{ml}$ blood in EDTA tube for DNA 
extraction, and $3 \mathrm{ml}$ for serum collection after centrifugation. Blood glucose was measured by using (Bionime blood glucose test strip that is an electrochemical method), lipid profile was done for each sample by enzymatic colorimetric methods using a Spectrophotometer ; total cholesterol ( CHOLESTEROL-LQ REF41020), triglycerides (TRIGLYCEIDES-LQ REF 41030) , HDL-C ( HDL Cholesterol P REF1001095 ), LDL-C is calculated using the Friedewald's equation, LDL-C $(\mathrm{mg} / \mathrm{dL})$ $=$ total cholesterol - HDL-C - triglycerides $/ 5$ ,and VLDL was calculated by using the Friedewald's equation; VLDL = Triglycerides/5) .

\section{Adiponectin level determination}

The human total adiponectin (ADPN) ELISA kit (96 Tests ;Catalog Number: MBS720699) was used to determined serum adiponectin concentration.

\section{DNA Extraction}

DNA was extracted from blood samples and collected in tubes containing EDTA with (TIANamp Genomic DNA Kit Wizard® Genomic DNA Purification Kit). The extracted DNA was conserved at $-20{ }^{\circ} \mathrm{C}$ till genotyping steps.

\section{Genotyping of Adiponectin gene polymorphism (276 G/T) using ARMS PCR method}

For each sample, 2 PCR reactions were done with two pairs of primers. The first PCR reaction is for wild allele, while the second PCR reaction for mutant allele. Primers for $1^{\text {st }}$ PCR reaction ( $\mathrm{G}$ allele), 5 - CCT CCT ACA CTG ATA TAA ACT ATA TGA GGG-3 ‘ and 5`-GAA TAT GAA TGT ACT GGG AAT AGG GAT G-3`. primers for $2^{\text {nd }}$ PCR Reaction (T allele), 5`- GAG CTG TTC TAC TGC TAT TAG CTC TGC-3`; and 5`- TGT GTC TAG GCC TTA GTT AAT AAT GAA CGA-3`. Each PCR reaction was done in a final volume of 20 $\mu \mathrm{L}$ ( $5 \mu \mathrm{L}$ DNA, $5 \mu \mathrm{L}$ of working primer mixture, and $10 \mu \mathrm{L} 2 \mathrm{x}$ master mix solution). Each PCR reaction was done at a final volume of $20 \mu \mathrm{L}$ containing $5 \mu \mathrm{L}$ DNA, 5 $\mu \mathrm{L}$ of dilute primer mixture, and $10 \mu \mathrm{L}$ master mix solution. PCR cycling conditions were $5 \mathrm{~min}$ at $95^{\circ} \mathrm{c}$ followed by 30 cycles of $30 \mathrm{~s}$ at $95^{\circ} \mathrm{c}, 27 \mathrm{~s}$ at $61^{\circ} \mathrm{c}$, and $25 \mathrm{~s}$ at 72 , with a final step at $72^{\circ} \mathrm{C}$ for 5 min to allow for complete extension of all PCR fragments. PCR products were amplified in a $2 \%$ agarose; (figure 1).

\section{Genotyping of Adiponectin gene polymorphism (+45T/G) using RFLP PCR method}

For each sample, one PCR reaction was done followed by digestion with a suitable restriction enzyme. The PCR primer sequences were 5 - GAA GTA GAC TCT GCT GAG ATG-3` (forward) and 5'-TAT CAG TGT AGG TCT GTG ATG-3 (reserve).A three-step PCR was standardized and carried out with an initial denaturation at $95^{\circ} \mathrm{C}$ for 5 minutes followed by cycling at $95^{\circ} \mathrm{C}$ for 45 seconds; $60.2^{\circ} \mathrm{C}$ annealing for 45 seconds, $72^{\circ} \mathrm{C}$ for 45 seconds extension and a final extension at $72^{\circ} \mathrm{C}$ for 7 minutes was carried out for about 35 cycles.PCR products are amplified to RFLP using the SmaI (\#R0141s NEW ENGLAND Biolabs) restriction enzyme for $37^{\circ} \mathrm{C}$ overnight digestion enzyme. PCR products were amplified in a $2 \%$ agarose (figure 2 ).

\section{Statistical analysis}

One-way ANOVA, followed by post hoc test was used for numerical parameters , through the general linear models (GLM) procedure of the statistical package for social sciences version 22.0 (IBM Corp., Armonk, NY, USA). For categorical data, Chi-square test was used to compare between patients and control subjects. Allele 
and genotype frequencies were calculated for each locus and for each population using the Pop gene on the web software, version 4.0.10. Genotype frequencies were tested in patients and controls for Hardy-Weinberg equilibrium (HWE) using Chi-square test (Exact Fisher's method when excepted cell frequency is less than 5). Armitage's trend test and Allele freq. difference test were used to test the significance in difference in genotype and allele frequencies distribution respectively between populations given each position. Logistic regression was performed under three genotype models ( co-dominant , dominant and recessive) in each position. The strength of association was estimated by the crude odds ratios (OR), with $95 \%$ confidence interval $(95 \% \mathrm{CI})$. The statistical significance was accepted for $\mathrm{p}<0.05$.Also adjusted odds ratio which were adjusted for age (AOR) were also estimated and tested.

Pearson correlation coefficient was estimated to test strength and direction of association between lipid profile parameters in control, overweight and obese subjects enrolled to the study. Data were expressed as mean \pm standard error of mean (SE) for continuous variables, also F-statistics, pvalues were reported. While results for categorical variables were reported as number and percent of patients.

\section{RESULTS:}

There were no statistically significant differences between obese people, overweight, and control subjects in gender $\left(\mathrm{X}^{2}=2.243, \mathrm{P}=0.297\right)$, Cholesterol ( $\mathrm{F}=1.58, \mathrm{P}=0.21)$, HDL $(\mathrm{F}=1.58, \mathrm{P}=0.21)$ , LDL ( $\mathrm{F}=0.50, \mathrm{P}=0.610$ ), and adiponectin concentration ( $\mathrm{F}=0.59, \mathrm{P}=0.558$ ), but there were highly significant differences in age $(\mathrm{F}=15.99, \mathrm{P}<0.0001)$, BMI ( $\mathrm{F}=226.94, \mathrm{P}<0.0001$ ), and glucose level ( $\mathrm{F}=5.23$, $\mathrm{P}=0.006$ ) , also significant difference in triglyceride (TG) ( $\mathrm{F}=3.39$,
$\mathrm{P}=0.036)$, and VLDL ( $\mathrm{F}=3.72, \mathrm{P}=0.026)$ ,(Table1) and (Table2).

For G276T polymorphism; The results show control subjects and obese patients are not in Hardy-Weinberg equilibrium $(\mathrm{P}<$ 0.0001, $\mathrm{P}=0.027$ ) respectively, while overweight patients are in HardyWeinberg equilibrium $(\mathrm{P}=0.658)$.

For T45G polymorphism, The results show that both genotype and allele proportions were in Hardy-Weinberg equilibrium in overweight, control and obese subjects ( $\mathrm{P}$ $=0.300, \mathrm{P}=0.300, \mathrm{P}=0.300)$ respectively. Armitage's trend test for G276T and T45G adiponectin polymorphism showed that there was no significant difference in genetic distribution among overweight patients and control subjects ( $\mathrm{P}=0.191, \mathrm{P}=0.513$ ) respectively, Also there was no significant difference in genetic distribution between obese patient and control subjects $(\mathrm{P}=0.128$, $\mathrm{P}=0.118$ ) respectively.

Allele frequencies difference test for G276T and $\mathrm{T} 45 \mathrm{G}$ adiponectin polymorphism showed that there was no significant difference in allele frequency between overweight patients and control subjects ( $\mathrm{P}$ $=0.147, \mathrm{P}=0.465$ ) respectively, also there was no significant difference in allele frequency between obese patients and control subjects $(\mathrm{P}=0.075, \mathrm{P}=0.089)$ respectively; (Table 3) and (Table 4).

\section{Association of adiponectin polymorphism G276T and T45G with biochemical parameters}

For G276T, Results show that heterozygous GT and homozygous GG carriers were associated with higher BMI $(\mathrm{F}=3.51$, $\mathrm{P}=0.032$ ) compared to TT carriers, but there weren't significant genotyping effect on cholesterol, triglyceride, HDL, LDL, VLDL, Glucose level and adiponectin concentration. While for T45G polymorphism, heterozygous GT and 
homozygous GG carriers were associated with higher $\mathrm{BMI} \quad(\mathrm{F}=3.60, \quad \mathrm{P}=0.029)$, triglyceride $(\mathrm{F}=3.62, \mathrm{P}=0.029)$, and VLDL $(\mathrm{F}=3.73, \mathrm{P}=0.026)$ compared to TT carriers, but there was no significant genotyping effect on cholesterol, HDL, LDL, Glucose level and adiponectin concentration. (Table 5), (Table 6).

\section{Adiponectin gene polymorphism and risk of obesity}

For G276T, it was associated with overweight under Co dominant and recessive models $(\mathrm{OR}=35.30,95 \% \mathrm{CI}=2.33$ 533.99, $\mathrm{P}=0.010)$, and $(\mathrm{OR}=3.21$, $95 \% \mathrm{CI}=1.08-9.51, \mathrm{P}=0.036)$ respectively (table4.1); while it was associated with obesity under a recessive model only $(\mathrm{OR}=2.91,95 \% \mathrm{CI}=1.01-8.41, \mathrm{P}=0.048)$.

For T45G, it was not associated with overweight under Co dominant, dominant and recessive models, While it was associated with Obesity under Co dominant and dominance models $(\mathrm{OR}=4.11$, 95\% $\mathrm{CI}=1.03-16.50, \mathrm{P}=0.046)$ and $(\mathrm{OR}=3.60$, $95 \% \mathrm{CI}=1.03-12.61, \mathrm{P}=0.045)$ and $(\mathrm{OR}=3.60$ ,95\% CI=1.03-12.61, $\mathrm{P}=0.045)$ respectively (Table 7), (Table 8), (Table 9), (Table 10).

\section{Relation between all biomedical parameters in all studied groups}

In control group, there was a significant positive correlation between cholesterol and HDL ( $r=1.000, p=0)$, Cholesterol with LDL $(\mathrm{r}=0.971, \mathrm{p}=0), \mathrm{TG}$ with VLDL $(\mathrm{r}=0.997$, $\mathrm{p}=0)$, and HDL with LDL $(\mathrm{r}=0.971, \mathrm{p}=0)$; as shown in (Table 11).

In overweight group, there was a significant positive correlation between cholesterol with HDL $(r=1.000, p=0)$, Cholesterol with LDL $(\mathrm{r}=0.971, \mathrm{p}=0)$, Cholesterol with TG $(\mathrm{r}=0.340$ , $\mathrm{p}=0.026)$, Cholesterol with VLDL $(\mathrm{r}=0.340$, $\mathrm{p}=0.026)$, TG with HDL $\quad(\mathrm{r}=0.340$, $\mathrm{p}=0.026), \mathrm{TG}$ with VLDL $(\mathrm{r}=1, \mathrm{p}=0)$, HDL with LDL $(r=0.976, p=0)$, and HDL with VLDL $(r=0.340, p=0.026)$; as shown in (Table 12).
In obese group, there was a significant positive correlation between cholesterol with HDL ( $\mathrm{r}=1.000, \mathrm{p}=0)$, Cholesterol with LDL $(\mathrm{r}=0.957, \mathrm{p}=0)$, cholesterol with glucose $(\mathrm{r}=0.469, \mathrm{p}=0), \mathrm{TG}$ with VLDL $(\mathrm{r}=1.000$, $\mathrm{p}=0)$, HDL with $\mathrm{LDL}(\mathrm{r}=0.957, \mathrm{p}=0)$, HDL with glucose $(r=0.469, p=0)$, and LDL with glucose $(r=0.460, p=0)$, and there was a significant negative correlation between BMI with adiponectin concentration ( $r=-$ $0.238, \mathrm{p}=0.025)$, TG with LDL $\quad(\mathrm{r}=-$ $0.306, p=0.004)$, and LDL with VLDL ( $r=-$ $0.306, p=0.004$ ); as shown in (Table 13).

\section{DISCUSSION:}

According to World Health Organization (WHO), obesity is one of the biggest challenges to public health in the $21^{\text {st }}$ century by 2015; more than 700 million adults are obese. Adiponectin is excreted by adipose tissues and its levels are inversely associated with body mass index. In this study, it was found that the cases of weight gain and obesity is strongly associated with $+45 \mathrm{~T} / \mathrm{G}$ and $+276 \mathrm{G} / \mathrm{T}$ genotype. It is suggested that ADIPOQ gene polymorphism can contribute significantly to weight gain. Furthermore, several studies showed that adiponectin is able to counter insulin resistance, atherosclerosis and inflammatory processes ${ }^{(23,24,25-27)}$. In 2002 Menzaghi et al. noted that the $+45 \mathrm{~T} / \mathrm{G}$ and $+276 \mathrm{G} / \mathrm{T}$ polymorphisms of the adiponectin gene contributed to weight gain and the development of insulin resistance ${ }^{(28)}$.

Many European, Asian and American societies have studied SNPs 45T $>\mathrm{G}$ and $276 \mathrm{G}>\mathrm{T}^{(29)}$. Even though there was a lack of consistency between the studies, the results indicated that genetic variation in the ADIPOQ gene was linked to insulin resistance and diabetes mellitus type $2^{(30,31)}$. Italy's Mediterranean population was associated with a $276 \mathrm{~T}$ allele with higher levels of insulin ${ }^{(32)}$, however other studies 
have shown adverse results ${ }^{(33,34)}$. Boumaiza et $a l^{(35)}$ noted the protective role of $\mathrm{G} 276 \mathrm{~T}$ SNP among Tunisians and also the same results appeared with Menzaghi et al. ${ }^{(36)}$ and Stumvoll et al. (37), but Fillipi et $a l^{(38)}$ pointed out that the $\mathrm{T}$ allele is linked to obesity risk and IR . It can be contrasted this discrepancy in part to ethnic Privacy. The present study showed that adiponectin polymorphism G276T was associated with overweight under Co dominant and recessive models $(\mathrm{OR}=35.30,95 \% \mathrm{CI}=2.33$ $533.99, \mathrm{P}=0.010)$, and $(\mathrm{OR}=3.21,95 \% \mathrm{CI}=$ $1.08-9.51, \mathrm{P}=0.036)$ respectively, adiponectin polymorphism G276T was associated with Obesity under recessive model $(\mathrm{OR}=2.91$, 95\% CI=1.01-8.41, $\mathrm{P}=0.048$ ) ; while The adiponectin polymorphism $\mathrm{T} 45 \mathrm{G}$ was associated with Obesity under Co dominant and dominance models $(\mathrm{OR}=4.11,95 \% \mathrm{CI}=$ $1.03-16.50, \mathrm{P}=0.046)$ and $(\mathrm{OR}=3.60,95 \% \mathrm{CI}=$ 1.03-12.61, $\mathrm{P}=0.045)$ respectively. $\mathrm{SNP}$ $276 \mathrm{G}>\mathrm{T}$ can influence the sensivity of insulin as it suggested that intronic SNPs may modify the levels of gene expression (39). Current results are consistent with previous data published by Jang and his team (40), where only among subjects who have a high BMI observed the phenotypic expression of the genotype for SNP G276T . In the non-diabetic Italian population, the highest IR observed among subjects with a genotype TT was more pronounced in lean compared to obese individuals ${ }^{(41)}$; The present study showed association between G276T and 45T/G genotypes with obesity parameter (BMI) and clinical biochemical parameters; there were highly significant differences in age $(\mathrm{F}=15.99, \mathrm{P}<0.0001)$, BMI $(\mathrm{F}=226.94, \mathrm{P}<0.0001)$, and glucose level $(\mathrm{F}=5.23, \mathrm{P}=0.006)$,also significant difference in triglyceride (TG) $(\mathrm{F}=3.39, \mathrm{P}=0.036) \quad$,and $\quad$ VLDL $(\mathrm{F}=3.72, \mathrm{P}=0.026)$. There was a significant negative correlation between $\mathrm{BMI}$ and adiponectin concentration $(r=-0.238, p=0.02$
) ,TG with LDL ( $\mathrm{r}=-0.306, \mathrm{p}=0.004)$, and LDL with VLDL ( $\mathrm{r}=-0.306, \mathrm{p}=0.004)$; in Obese group; as shown in (table 6.3), Compared to correlation between BMI with adiponectin concentration in overweight group and control group.

\section{CONCLUSION}

The presence of alleles TT and GT at the 276 locus of the ADIPOQ gene are related to an increase in BMI, while alleles TG and GG at the 45 locus of the ADIPOQ gene are related to an increase in BMI, triglyceride, and VLDL in Egyptian people. The study proposed that the ADIPOQ G276T and ADIPOQ T45G polymorphisms may be useful indicators related to obesity and its associated complications. Early diagnosis may help to allocate of intensive interventions that may benefit children most vulnerable to obesity.

\section{REFERENCES:}

1. Must A, Colditz G ,Spadano J, Coakley EH ,Dietz WH, Field AE , (1999). The Disease Burden Associated With Overweight and Obesity. JAMA; 282 (16) :1523-1529.

2. Allison DB, Fontaine KR, VanItallie TB ,Manson JE, Stevens J, (1999). Annual Deaths Attributable to Obesity in the United States. JAMA; 282(16) :1530-1538.

3.Calle EE, Heath CW Thun MJ, Petrelli JM, Rodriguez C (1999). Body-mass index and mortality in a prospective cohort of US adults. N Engl J Med;341:1097-1105

4. Robert H. Eckel, Sachiko T. St. Jeor, David A. York, Stephan Rössner, Ian Caterson, VanHubbard ,Laura L. Hayman, Rebecca M. Mullis and Steven N. Blair (2004). Prevention Conference VII.

Circulation ;110(18):2968-2975. 
5.Benjamin Caballero; The Global Epidemic of Obesity (2007). An Overview, Epidemiologic ; 29(1) 1-5.

6. WHO Working Group. (1986). Use and interpretation of anthropometric indicators of nutritional status. Bulletin of the World Health Organization, 64(6), 929-941.

7. Flegal KM, Ogden CL, Carroll MD, Johnson CL (1999-2000). Prevalence and Trends in Obesity Among US Adults. JAMA. 2002;288(14):1723-1727.

8. Rashid, M. N., Fuentes, F., Touchon, R. C. and Wehner, P. S. (2003). Obesity and the Risk for Cardiovascular Disease. Preventive Cardiology, 6: 42-47.

9. David E. Cummings and Michael W. Schwartz (2003) .Genetics and pathophysiology of human obesity. Annual Review of Medicine .; 453:453-471.

10. Michael W. Schwartz.(2001). Brain pathways controlling food intake and body weight. Experimental Biology and Medicine ;226( 11)978 - 981.

11.Mora S, Pessin JE.( 2002) An adipocentric view of signaling and intracellular trafficking. Diabetes Metab Res Rev. Sep- Oct ; 18(5):345-356.

12. Cottam D.R., Schaefer P.A., Shaftan, G.W. et al. OBES SURG (2002). Effect of surgically-induced weight loss on leukocyte indicators of chronic inflammation in morbid obesity. Obes Surg. 12(3):335-42. 12: 335 .

13. Das UN.Is obesity an inflammatory condition?. (2001). Nutrition.; 17(1112):953-66.

14. Philipp E. Scherer ,Suzanne Williams , Michael Fogliano, Giulia Baldini , Harvey F. Lodish. (1995). Anovel serum protein similar to C1q, produced exclusively in adipocytes. J Biol Chem. ; 270(45):26746-9.
15. Berg, Anders H., et al. (2001). "The adipocyte-secreted protein Acrp30 enhances hepatic insulin action." Nature medicine 7.8: 947-953.

16. Tschritter O., Shirkavand, F ,Fritsche A., Thamer C., Stumvoll, M. Haap M., Rahe S, (2003). Plasma adiponectin concentrations predict insulin sensitivity of both glucose and lipid metabolism. Diabetes, 52(2), 239243.

17. Mi J., Cianflone K ,Munkonda M. N., Zhang M. X., Li M., Zhao X. Y., Fouejeu P. C. W,. (2010). Adiponectin and leptin metabolic biomarkers in chinese children and adolescents. Journal of obesity, 2010.

18. Yu D., Yu Z., Zhang G, Sun Q., Sun L., Li H., Song J.,. (2011). Effects of body fat on the associations of high-molecularweight adiponectin, leptin and soluble leptin receptor with metabolic syndrome in Chinese. PloS one, 6(2), e16818.

19. Takahashi M., Matsukawa Y Arita Y., Yamagata K.,., Horie M., Okutomi K., Nakamura T. (2000). Genomic structure and mutations in adipose-specific gene, adiponectin . International journal of obesity, 24(7), 861.

20. Heid I. M., Mueller J. C., Wagner S. A., Iglseder B., Gohlke H., Cip P., Illig, T. (2006). Genetic architecture of the APM1 gene and its influence on adiponectin plasma levels and parameters of the metabolic syndrome in 1,727 healthy Caucasians. Diabetes, 55(2), 375-384.

21. Ling H., Kesäniemi Y. A., Waterworth D. M., Stirnadel H. A., Pollin T. I., Barter P. J.,..Cohen, J. C. (2009). Genome-wide Linkage and Association Analyses to Identify Genes Influencing Adiponectin Levels: The GEMS Stud. Obesity, 17(4), 737-74422.

22 Gable D. R., ., Humphries S. E. ,Matin J., Whittall R., Cakmak H., Li K. W., Cooper J (2007). Common adiponectin gene variants show different effects on risk of 
cardiovascular disease and type 2 diabetes in European subjects. Annals of human genetics, 71(4), 453-466

23. Šenolt L., Haluzik M. ,Pavelka K., Housa D., (2006). Increased adiponectin is negatively linked to the local inflammatory process in patients with rheumatoid arthritis. Cytokine, 35(5), 247-252

24. Toussirot E., Wendling D ,Streit G. (2007). The contribution of adipose tissue and adipokines to inflammation in joint diseases. Current medicinal chemistry, 14(10), 1095-1100.

25. Fantuzzi G. (2008). Adiponectin and inflammation:consensus and controversy. Journal of Allergy and Clinical Immunology, 121(2), 326-330.

26. Yamauchi T., Uchida S., Kamon J., Minokoshi Y. A., Waki H., Ito Y., Eto K. (2002). Adiponectin stimulates glucose utilization and fatty-acid oxidation by activating AMP-activated protein kinase. Nature medicine, 8(11), 1288-1295. 27. Von Eynatten M., Rothenbacher D ,Hamann A., Twardella D., Nawroth P. P., Brenner H.,. (2006). Relationship of adiponectin with markers of systemic inflammation, atherogenic dyslipidemia, and heart failure in patients with coronary heart disease. Clinical chemistry, 52(5), 853-859. 28. Menzaghi C., Warram J. H., Ercolino T., Di Paola R., Berg A. H., Scherer P. E., Doria A. (2002). A haplotype at the adiponectin locus is associated with obesity and other features of the insulin resistance syndrome. Diabetes, 51(7), 2306-2312.

29. Vasseur F., Froguel P Meyre D. (2006). Adiponectin, type 2 diabetes and the metabolic syndrome: lessons from human genetic studies. Expert reviews in molecular medicine, 8(27), 1-12

30. Hu F. B., Manson J. E ,Doria A., Li T., Meigs J. B., Liu S., Memisoglu A... (2004). Genetic variation at the adiponectin locus and risk of type 2 diabetes in women. Diabetes, 53(1), 209-213
31. Richardson D. K., Rodriguez L. M., Schneider J., Fourcaudot M. J., Arya R., Dyer T. D., Duggirala, R. (2006). Association between variants in the genes for adiponectin and its receptors with insulin resistance syndrome (IRS)-related phenotypes in Mexican Americans. Diabetologia , 49(10), 23172328

32.Salmenniemi U., Laakso M. ,Zacharova J., Ruotsalainen E., Pihlajamäki J., Kainulainen S, Vauhkonen I. (2005). Association of adiponectin level and variants in the adiponectin gene with glucose metabolism, energy expenditure, and cytokines in offspring of type 2 diabetic patients. The Journal of Clinical Endocrinology \& Metabolism, 90(7), 42164223.

33. Xita N., Georgiou I., Chatzikyriakidou A., Vounatsou M., Tsatsoulis A ,Papassotiriou G. P., Papassotiriou I.,. (2005). Effect of adiponectin gene polymorphisms on circulating adiponectin and insulin resistance indexes in women with polycystic ovary syndrome. Clinical chemistry, 51(2), 416-42.

34. Jang Y., Ordovas J. M , Kim O. Y., Koh S. J., Chae J. S., Woo J. H., Lee J. H. . (2006). The SNP276G> T polymorphism in the adiponectin (ACDC) gene is more strongly associated with insulin resistance and cardiovascular disease risk than SNP45T> $G$ in nonobese/nondiabetic Korean men independent of abdominal adiposity and circulating plasma adiponectin. Metabolism, 55(1), 59-66

35. Boumaiza I., Bouslama A.,Omezzine A., Rejeb J., ., Nabli N ,Rebhi L., Rejeb N. B .(2011). Association between eight adiponectin polymorphisms, obesity, and metabolic syndrome parameters in Tunisian volunteers. Metabolic syndrome and related disorders, 9(6), 419-426 
36. Menzaghi C., Ercolino T., Di Paola R., Berg A. H., Warram J. H., Scherer P. E., Doria A. (2002). A haplotype at the adiponectin locus is associated with obesity and other features of the insulin resistance syndrome. Diabetes, 51(7), 2306-2312

37. Stumvoll M., Weisser M, Renn W.,Tschritter O., Fritsche A., Staiger H.,Häring H. (2002). Association of the TG polymorphism in adiponectin (exon 2) with obesity and insulin sensitivity. Diabetes, 51(1), 37-41

38. Filippi E., Baroni M. G ,Sentinelli F., Trischitta V., Romeo,S., Arca M., Leonetti F., . (2004). Association of the human adiponectin gene and insulin resistance. European Journal of Human Genetics, 12(3), 199-205.
39. Horikawa Y., Cox N. J., Li X., OrhoMelander M., Hara M., Oda N., del BosquePlata L. (2000). Genetic variation in the gene encoding calpain-10 is associated with type 2 diabetes mellitus. Nature genetics, 26(2), 163-17.

40. Jang Y., Chae J. S., Kim O. Y., Koh S. J., Kim J. Y., Ordovas J. M. Lee J. H. (2005). Association of the $276 \mathrm{G} \rightarrow \mathrm{T}$ polymorphism of the adiponectin gene with cardiovascular disease risk factors in nondiabetic Koreans. The American journal of clinical nutrition, 82(4), 760-767.

41. Filippi E., Sentinelli F., Trischitta V., Romeo, S., Arca M., Leonetti F., Baroni M. G. (2004). Association of the human adiponectin gene and insulin resistance. European Journal of Human Genetics, 12(3), 199-205.

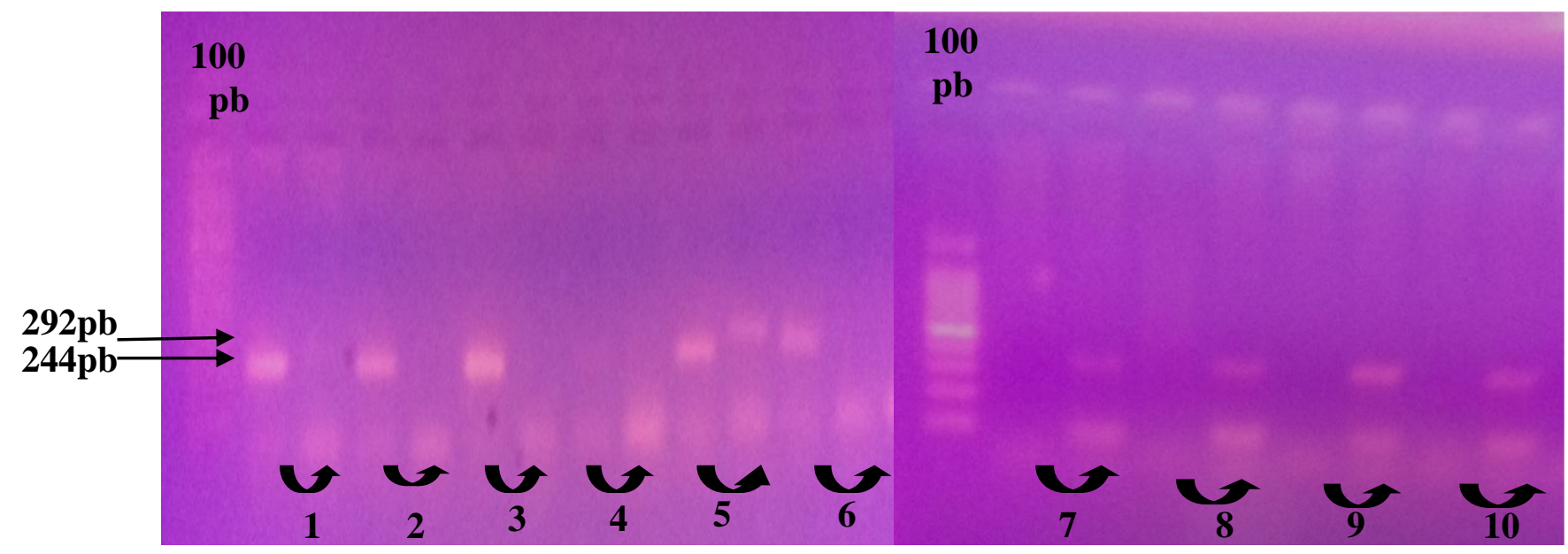

Figure 1. Genetics patterns of adiponectin polymorphism on the electrode gel with staining of ethidium bromide and UV light. Molecular weight DNA standard marker (100pb), 11:-ve ; 5and12: Heterozygous mutant (GT); 1,2,3, and6: Homozygous mutant (GG) 244pb; 7,8,9,10and13 : Homozygous wild type (TT) 292pb. 


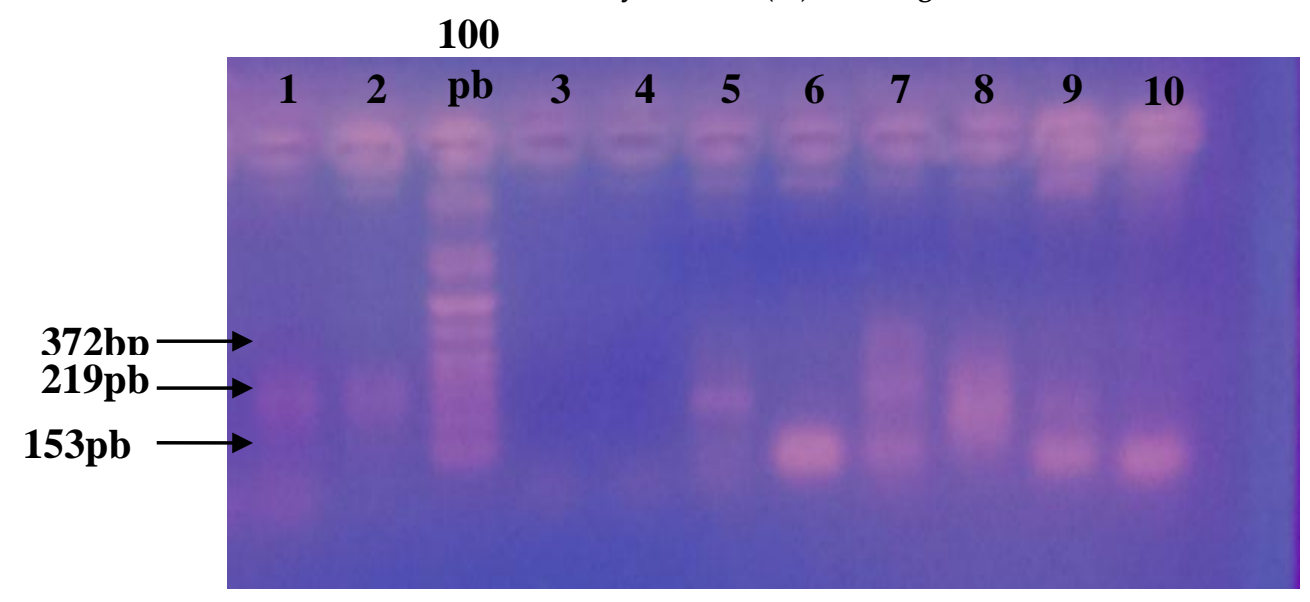

Figure 2. Restriction enzyme digestion (SmaI) of PCR products. Genetics patterns of adiponectin polymorphism on the electrode gel with staining of ethidium bromide and UV light. Molecular weight DNA marker. Lanes 7,and 14: heterozygote TG 372, 219 and 153bp. Lane1,2,5,8 and 15: Homozygous mutant (GG), Lanes 11,12,13,16,17,18,19, and20: Wild type 372 bp TT genotype Lane. 
Table 1: Demographic characteristics of patients and control enrolled in the study $(n=172)$

\begin{tabular}{|c|c|c|c|c|c|c|}
\hline \multicolumn{2}{|c|}{} & $\begin{array}{c}\text { Control } \\
(\mathrm{n}=40)\end{array}$ & $\begin{array}{c}\text { Over weight } \\
(\mathrm{n}=43)\end{array}$ & $\begin{array}{c}\text { Obese } \\
(\mathrm{n}=89)\end{array}$ & F-value & P-value \\
\hline \multicolumn{2}{|c|}{ Age } & $\begin{array}{c}27.83 \pm 1.62^{\mathrm{c}} \\
(16-59)\end{array}$ & $\begin{array}{c}32.93 \pm 1.76^{\mathrm{b}} \\
(15-56)\end{array}$ & $\begin{array}{c}39.39 \pm 1.2^{\mathrm{a}} \\
(15-57)\end{array}$ & $15.99^{* *}$ & $<0.0001$ \\
\hline \multicolumn{2}{|c|}{ BMI } & $\begin{array}{c}22.63 \pm 0.29^{\mathrm{c}} \\
(18-25)\end{array}$ & $\begin{array}{c}27.04 \pm 0.19^{\mathrm{b}} \\
(24.96-29.66)\end{array}$ & $\begin{array}{c}35.39 \pm 0.47^{\mathrm{a}} \\
(30-50)\end{array}$ & $226.94^{* *}$ & $<0.0001$ \\
\hline \multirow{2}{*}{ Gender } & $\mathrm{F}$ & $18(45.0 \%)$ & $18(41.9 \%)$ & $49(55.1 \%)$ & \multirow{2}{*}{$\chi^{2}=2.43^{\mathrm{NS}}$} & 0.297 \\
\cline { 2 - 6 } & $\mathrm{N}$ & $22(55.0 \%)$ & $25(58.1 \%)$ & $40(44.9 \%)$ & & \\
\hline
\end{tabular}

Means within the same row carrying different superscripts are sig. different at $\mathrm{P}<0.05$ based on Bonferroni's multiple comparison test.;: indicate significant difference $(\mathrm{P}<0.05) ; * *$ : indicate highly significant difference $(\mathrm{P}<0.01)$;NS: indicate non-significant difference.

Table 2: Comparison of clinical parameters among overweight, obese patients and control

\begin{tabular}{|c|c|c|c|c|c|}
\hline & $\begin{array}{c}\text { Control } \\
(\mathrm{n}=40)\end{array}$ & $\begin{array}{c}\text { Over weight } \\
(\mathrm{n}=43)\end{array}$ & $\begin{array}{c}\text { Obese } \\
(\mathrm{n}=89)\end{array}$ & F-value & P-value \\
\hline Cholesterol & $\begin{array}{c}164.76 \pm 7.28^{\mathrm{a}} \\
(105.54-310.82)\end{array}$ & $\begin{array}{c}180.35 \pm 8.24^{\mathrm{a}} \\
(102.37-280.2)\end{array}$ & $\begin{array}{c}181.41 \pm 5.47^{\mathrm{a}} \\
(101.32-313.46)\end{array}$ & $1.58^{\mathrm{NS}}$ & 0.210 \\
\hline TG & $\begin{array}{c}90.16 \pm 7.54^{\mathrm{b}} \\
(51.38-231.19)\end{array}$ & $\begin{array}{c}116.13 \pm 7.18^{\mathrm{ab}} \\
(59.17-238.53)\end{array}$ & $\begin{array}{c}116.62 \pm 6.66^{\mathrm{a}} \\
(63.3-521.1)\end{array}$ & $3.39^{*}$ & 0.036 \\
\hline HDL & $\begin{array}{c}32.95 \pm 1.46^{\mathrm{a}} \\
(21.11-62.16)\end{array}$ & $\begin{array}{c}36.07 \pm 1.65^{\mathrm{a}} \\
(20.47-56.04)\end{array}$ & $\begin{array}{c}36.28 \pm 1.09^{\mathrm{a}} \\
(20.26-62.69)\end{array}$ & $1.58^{\mathrm{NS}}$ & 0.210 \\
\hline LDL & $\begin{array}{c}113.97 \pm 5.93^{\mathrm{a}} \\
(65.57-233.15)\end{array}$ & $\begin{array}{c}121.08 \pm 6.25^{\mathrm{a}} \\
(66.32-206)\end{array}$ & $\begin{array}{c}121.59 \pm 4.62^{\mathrm{a}} \\
(40.14-233.6)\end{array}$ & $0.50^{\mathrm{NS}}$ & 0.610 \\
\hline VLDL & $\begin{array}{c}17.83 \pm 1.41^{\mathrm{b}} \\
(10.28-42.24)\end{array}$ & $\begin{array}{c}23.2 \pm 1.44^{\mathrm{ab}} \\
(11.83-47.7)\end{array}$ & $\begin{array}{c}23.32 \pm 1.33^{\mathrm{a}} \\
(12.66-104.22)\end{array}$ & $3.72^{*}$ & 0.026 \\
\hline Glucose & $\begin{array}{c}101.63 \pm 2.38^{\mathrm{b}} \\
(70-153)\end{array}$ & $\begin{array}{c}106.05 \pm 3.45^{\mathrm{ab}} \\
(78-212)\end{array}$ & $\begin{array}{c}134.93 \pm 9.02^{\mathrm{a}} \\
(74-515)\end{array}$ & $5.23^{* *}$ & 0.006 \\
\hline Adiponectin & $\begin{array}{c}19.99 \pm 1.95^{\mathrm{a}} \\
(10.58-52.11)\end{array}$ & $\begin{array}{c}17.41 \pm 1.43^{\mathrm{a}} \\
(10.58-51.26)\end{array}$ & $\begin{array}{c}18.84 \pm 1.16^{\mathrm{a}} \\
(8.85-54.29)\end{array}$ & $0.59^{\mathrm{NS}}$ & 0.558 \\
\hline
\end{tabular}

Means within the same row carrying different superscripts are sig. different at $\mathrm{P}<0.05$ based on Bonferroni's multiple comparison test. *: indicate significant difference $(\mathrm{P}<0.05)$; **: indicate highly significant difference $(\mathrm{P}<0.01)$;NS: indicate non-significant difference 
Table 3: Distribution of adiponectin polymorphism G276T and T45G (Genotype and Allele) frequencies among Over weight patients and controls.

\begin{tabular}{|c|c|c|c|c|c|c|c|}
\hline \multirow{2}{*}{ G276T } & \multicolumn{3}{|c|}{ Genotypes } & \multicolumn{2}{|c|}{ Allele } & \multirow{2}{*}{$\begin{array}{c}\chi^{2} \\
(\mathrm{HWE})\end{array}$} & \multirow{2}{*}{ P value* } \\
\hline & GG & GT & TT & $\mathrm{G}$ & $\mathrm{T}$ & & \\
\hline $\begin{array}{l}\text { Control } \\
(n=40)\end{array}$ & $4(10.0 \%)$ & $2(5.0 \%)$ & $34(85.0 \%)$ & $10 / 80$ & $70 / 80$ & 23.804 & $<0.0001$ \\
\hline $\begin{array}{c}\text { Over } \\
\text { weight } \\
(n=43)\end{array}$ & $1(2.3 \%)$ & $16(37.2 \%)$ & $26(60.5 \%)$ & $18 / 86$ & $68 / 86$ & 0.663 & 0.658 \\
\hline P-value & \multicolumn{3}{|c|}{$\begin{array}{l}\text { Armitage's trend test } \\
0.191\end{array}$} & \multicolumn{2}{|c|}{$\begin{array}{c}\text { Allele freq. } \\
\text { difference } \\
0.147\end{array}$} & & \\
\hline \multirow{2}{*}{ T45G } & \multicolumn{3}{|c|}{ Genotypes } & \multicolumn{2}{|c|}{ Allele } & \multirow{2}{*}{$\begin{array}{c}\chi^{2} \\
(\mathrm{HWE})\end{array}$} & \multirow{2}{*}{$P$ value } \\
\hline & $\mathrm{TT}$ & GT & GG & $\mathrm{T}$ & G & & \\
\hline $\begin{array}{l}\text { Control } \\
(n=40)\end{array}$ & $36(90.0 \%)$ & $3(7.5 \%)$ & $1(2.5 \%)$ & $75 / 80$ & $5 / 80$ & 5.184 & 0.124 \\
\hline $\begin{array}{c}\text { Over } \\
\text { weight } \\
(n=43)\end{array}$ & $36(83.7 \%)$ & $6(14.0 \%)$ & $1(2.3 \%)$ & $78 / 86$ & $8 / 86$ & 1.288 & 0.300 \\
\hline P-value & \multicolumn{3}{|c|}{$\begin{array}{c}\text { Armitage's trend test } \\
0.513\end{array}$} & \multicolumn{2}{|c|}{$\begin{array}{c}\text { Allele freq. } \\
\text { difference } \\
0.465\end{array}$} & & \\
\hline
\end{tabular}

*: Probability value of Fisher's exact test

Table 4: Distribution of adiponectin polymorphism G276T and T45G (Genotype and Allele) frequencies among obese patients and controls.

\begin{tabular}{|c|c|c|c|c|c|c|c|}
\hline \multirow{2}{*}{ G276T } & \multicolumn{3}{|c|}{ Genotypes } & \multicolumn{2}{|c|}{ Allele } & \multirow{2}{*}{$\begin{array}{c}\chi^{2} \\
(\mathrm{HWE})\end{array}$} & \multirow{2}{*}{$\mathrm{P}$ value* } \\
\hline & GG & GT & TT & $\mathrm{G}$ & $\mathrm{T}$ & & \\
\hline $\begin{array}{l}\text { Control } \\
(n=40)\end{array}$ & $4(10.0 \%)$ & $2(5.0 \%)$ & $34(85.0 \%)$ & $10 / 80$ & $70 / 80$ & 23.804 & $<0.0001$ \\
\hline $\begin{array}{l}\text { Obese } \\
(\mathrm{n}=89)\end{array}$ & $8(9.0 \%)$ & $23(25.8 \%)$ & $58(65.2 \%)$ & $39 / 178$ & $139 / 178$ & 5.33 & 0.027 \\
\hline P-value & \multicolumn{3}{|c|}{$\begin{array}{c}\text { Armitage's trend test } \\
0.128 \\
\end{array}$} & \multicolumn{2}{|c|}{$\begin{array}{l}\text { Allele freq. difference } \\
0.075\end{array}$} & & \\
\hline \multirow{2}{*}{ T45G } & \multicolumn{3}{|c|}{ Genotypes } & \multicolumn{2}{|c|}{ Allele } & & P value \\
\hline & TT & TG & GG & $\mathrm{T}$ & $\mathrm{G}$ & (HWE) & \\
\hline $\begin{array}{l}\text { Control } \\
(n=40)\end{array}$ & $36(90.0 \%)$ & $75 / 80$ & 5.184 & 0.124 & $5 / 80$ & 5.184 & 0.124 \\
\hline $\begin{array}{l}\text { Obese } \\
(n=89)\end{array}$ & $68(76.4 \%)$ & $154 / 178$ & 1.58 & 0.186 & $24 / 178$ & 1.58 & 0.186 \\
\hline $\mathrm{P}$-value & \multicolumn{3}{|c|}{$\begin{array}{c}\text { Armitage's trend test } \\
0.118\end{array}$} & \multicolumn{2}{|c|}{$\begin{array}{l}\text { Allele freq. difference } \\
0.089\end{array}$} & & \\
\hline
\end{tabular}

*: Probability value of Fisher's exact test 
Table 5: Association of genotypes at adiponectin polymorphism G276Twith clinical and biochemical parameters.

\begin{tabular}{|c|c|c|c|c|c|}
\hline & $\begin{array}{c}\text { GG } \\
(\mathrm{n}=13)\end{array}$ & $\begin{array}{c}\text { GT } \\
(\mathrm{n}=41)\end{array}$ & $\begin{array}{c}\text { TT } \\
(\mathrm{n}=118)\end{array}$ & F-value & P-value \\
\hline BMI & $29.99 \pm 1.87^{\mathrm{ab}}$ & $32.61 \pm 1.02^{\mathrm{a}}$ & $29.58 \pm 0.57^{\mathrm{b}}$ & $3.51^{*}$ & 0.032 \\
\hline Cholesterol & $168.78 \pm 11.66$ & $167.22 \pm 7.74$ & $181.7 \pm 4.82$ & $1.42^{\mathrm{NS}}$ & 0.245 \\
\hline TG & $142.2 \pm 33.4$ & $108.4 \pm 5.84$ & $107.51 \pm 4.71$ & $2.26^{\mathrm{NS}}$ & 0.108 \\
\hline HDL & $33.75 \pm 2.33$ & $33.44 \pm 1.55$ & $36.34 \pm 0.96$ & $1.42^{\mathrm{NS}}$ & 0.245 \\
\hline LDL & $106.58 \pm 9.24$ & $112.1 \pm 6.04$ & $123.77 \pm 3.94$ & $1.93^{\mathrm{NS}}$ & 0.148 \\
\hline VLDL & $28.44 \pm 6.68$ & $21.65 \pm 1.17$ & $21.43 \pm 0.93$ & $2.33^{\mathrm{NS}}$ & 0.100 \\
\hline Glucose & $135.77 \pm 22.31$ & $123.83 \pm 9.87$ & $116.97 \pm 5.86$ & $0.59^{\mathrm{NS}}$ & 0.558 \\
\hline Adiponectin & $24.5 \pm 3.94$ & $17.06 \pm 1.29$ & $18.71 \pm 1.03$ & $2.34^{\mathrm{NS}}$ & 0.100 \\
\hline
\end{tabular}

Means within the same row carrying different superscripts are sig. different at $\mathrm{P}<0.05$ based on Bonferroni's multiple comparison test.; : indicate significant difference $(\mathrm{P}<0.05) ; * *$ : indicate highly significant difference $(\mathrm{P}<0.01)$;NS: indicate non-significant difference.

Table 6: Association of genotypes at adiponectin polymorphism T45Gwith clinical and biochemical parameters.

\begin{tabular}{|c|c|c|c|c|c|}
\hline & $\begin{array}{c}\text { TT } \\
(\mathrm{n}=140)\end{array}$ & $\begin{array}{c}\text { TG } \\
(\mathrm{n}=27)\end{array}$ & $\begin{array}{c}\text { GG } \\
(\mathrm{n}=5)\end{array}$ & F-value & P-value \\
\hline BMI & $29.74 \pm 0.51^{\mathrm{b}}$ & $33.29 \pm 1.44^{\mathrm{a}}$ & $30.89 \pm 3.76^{\mathrm{ab}}$ & $3.60^{*}$ & 0.029 \\
\hline Cholesterol & $176.92 \pm 4.24$ & $183.5 \pm 11.17$ & $153.53 \pm 17.81$ & $0.74^{\mathrm{NS}}$ & 0.479 \\
\hline TG & $107.47 \pm 3.6^{\mathrm{b}}$ & $113.2 \pm 12.98^{\mathrm{ab}}$ & $175.5 \pm 87.41^{\mathrm{a}}$ & $3.62^{*}$ & 0.029 \\
\hline HDL & $35.38 \pm 0.85$ & $36.7 \pm 2.23$ & $30.71 \pm 3.56$ & $0.74^{\mathrm{NS}}$ & 0.479 \\
\hline LDL & $119.97 \pm 3.39$ & $124.16 \pm 9.3$ & $87.72 \pm 14.22$ & $1.66^{\mathrm{NS}}$ & 0.193 \\
\hline VLDL & $21.43 \pm 0.71^{\mathrm{b}}$ & $22.64 \pm 2.6^{\mathrm{ab}}$ & $35.1 \pm 17.48^{\mathrm{a}}$ & $3.73^{*}$ & 0.026 \\
\hline Glucose & $115.89 \pm 4.85$ & $144.85 \pm 18.28$ & $101.6 \pm 8.24$ & $2.53^{\mathrm{NS}}$ & 0.083 \\
\hline Adiponectin & $18.77 \pm 0.94$ & $18.02 \pm 1.71$ & $22.11 \pm 7.6$ & $0.30^{\mathrm{NS}}$ & 0.744 \\
\hline
\end{tabular}

Means within the same row carrying different superscripts are sig. different at $\mathrm{P}<0.05$ based on Bonferroni's multiple comparison test.; $*$ indicate significant difference $(\mathrm{P}<0.05) ; * *$ : indicate highly significant difference $(\mathrm{P}<0.01)$;NS: indicate non-significant difference. 
Table 7: Association of genotypes at adiponectin polymorphism G276Twith overweight under co dominant, dominance ,and recessive models

\begin{tabular}{|c|c|c|c|c|c|c|}
\hline $\begin{array}{l}\text { Co dominant } \\
\text { model }\end{array}$ & $\begin{array}{l}\text { Control } \\
(n=40)\end{array}$ & $\begin{array}{l}\text { Overweight } \\
\quad(n=43)\end{array}$ & $\begin{array}{c}{ }^{\mathrm{c}} \mathrm{OR} \\
(95 \% \mathrm{CI})\end{array}$ & $\mathrm{P}$-value & $\begin{array}{c}{ }^{\mathrm{a}} \mathrm{OR} \\
(95 \% \mathrm{CI})\end{array}$ & P-value \\
\hline $\mathrm{GG}^{\mathrm{R}}$ & $4(80.0 \%)$ & $\begin{array}{c}1 \\
(20.0 \%)\end{array}$ & 1 & 0.006 & 1 & 0.009 \\
\hline GT & $2(11.1 \%)$ & $\begin{array}{c}16 \\
(88.9 \%)\end{array}$ & $\begin{array}{c}32.00 \\
(2.29-447.83)\end{array}$ & 0.010 & $\begin{array}{c}35.30 \\
2.33-533.99\end{array}$ & 0.010 \\
\hline $\mathrm{TT}$ & $\begin{array}{c}34 \\
(56.7 \%)\end{array}$ & $\begin{array}{c}26 \\
(43.3 \%) \\
\end{array}$ & $\begin{array}{c}3.06 \\
(0.32-29.02)\end{array}$ & 0.330 & $\begin{array}{c}3.86 \\
0.37-39.99\end{array}$ & 0.258 \\
\hline $\begin{array}{c}\text { Dominance } \\
\text { model }\end{array}$ & $\begin{array}{l}\text { Control } \\
(n=40)\end{array}$ & $\begin{array}{l}\text { Overweight } \\
\quad(n=43)\end{array}$ & $\begin{array}{c}{ }^{\mathrm{c}} \mathrm{OR} \\
(95 \% \mathrm{CI})\end{array}$ & P-value & $\begin{array}{c}{ }^{\mathrm{a}} \mathrm{OR} \\
(95 \% \mathrm{CI})\end{array}$ & P-value \\
\hline $\mathrm{GG}^{\mathrm{R}}$ & $4(80.0 \%)$ & $\begin{array}{c}1 \\
(20.0 \%)\end{array}$ & 1 & \multirow{2}{*}{0.177} & 1 & \multirow{2}{*}{0.134} \\
\hline $\mathrm{GT}+\mathrm{TT}$ & $\begin{array}{c}36 \\
(46.2 \%) \\
\end{array}$ & $\begin{array}{c}42 \\
(53.8 \%) \\
\end{array}$ & $\begin{array}{c}4.67 \\
0.50-43.66 \\
\end{array}$ & & $\begin{array}{c}6.02 \\
(0.58-62.97) \\
\end{array}$ & \\
\hline $\begin{array}{c}\text { recessive } \\
\text { model }\end{array}$ & $\begin{array}{c}\text { Control } \\
(\mathrm{n}=40)\end{array}$ & $\begin{array}{l}\text { Overweight } \\
(n=43)\end{array}$ & $\begin{array}{c}{ }^{\mathrm{c}} \mathrm{OR} \\
(95 \% \mathrm{CI}) \\
\end{array}$ & P-value & $\begin{array}{c}{ }^{\mathrm{a}} \mathrm{OR} \\
(95 \% \mathrm{CI})\end{array}$ & P-value \\
\hline $\mathrm{TT}^{\mathrm{R}}$ & $\begin{array}{c}34 \\
(56.7 \%)\end{array}$ & $\begin{array}{c}26 \\
(43.3 \%) \\
\end{array}$ & 1 & \multirow{2}{*}{0.016} & \multirow{2}{*}{$\begin{array}{c}3.21 \\
(1.08-9.51)\end{array}$} & \multirow{2}{*}{0.036} \\
\hline $\mathrm{GT}+\mathrm{GG}$ & $\begin{array}{c}6 \\
(26.1 \%)\end{array}$ & $\begin{array}{c}17 \\
(73.9 \%)\end{array}$ & $\begin{array}{c}3.71 \\
(1.28-10.71)\end{array}$ & & & \\
\hline
\end{tabular}

Reference, ${ }^{\mathrm{C} O R}$; Crude odds ratio, ${ }^{\mathrm{a}} \mathrm{OR}$; adjusted odds ratio for age CI: confidence interval

Table 8: Association of genotypes at adiponectin polymorphism T45G with overweight under co dominant, dominant, recessive model.

\begin{tabular}{|c|c|c|c|c|c|c|}
\hline $\begin{array}{c}\text { co dominant } \\
\text { model }\end{array}$ & $\begin{array}{l}\text { Control } \\
(\mathrm{n}=40)\end{array}$ & $\begin{array}{c}\text { Overweight } \\
(\mathrm{n}=43)\end{array}$ & ${ }^{\mathrm{c}} \mathrm{OR}(95 \% \mathrm{CI})$ & P-value & $\begin{array}{c}{ }^{\mathrm{a}} \mathrm{OR} \\
(95 \% \mathrm{CI})\end{array}$ & P-value \\
\hline $\mathrm{TT}^{\mathrm{R}}$ & $36(50.0 \%)$ & $\begin{array}{c}36 \\
(50.0 \%)\end{array}$ & 1 & 0.648 & 1 & 0.635 \\
\hline GT & $3(33.3 \%)$ & $\begin{array}{c}6 \\
(66.7 \%) \\
\end{array}$ & $\begin{array}{c}2.00 \\
(0.46-8.62) \\
\end{array}$ & 0.352 & $\begin{array}{c}1.97 \\
0.43-8.98 \\
\end{array}$ & 0.379 \\
\hline GG & $1(50.0 \%)$ & $\begin{array}{c}1 \\
(50.0 \%) \\
\end{array}$ & $\begin{array}{c}1 \\
(0.06-16.61) \\
\end{array}$ & 1 & $\begin{array}{c}1.84 \\
0.10-32.45 \\
\end{array}$ & 0.677 \\
\hline $\begin{array}{c}\text { dominant } \\
\text { model }\end{array}$ & $\begin{array}{l}\text { Control } \\
(\mathrm{n}=40)\end{array}$ & $\begin{array}{c}\text { Overweight } \\
(\mathrm{n}=43)\end{array}$ & ${ }^{\mathrm{c}} \mathrm{OR}(95 \% \mathrm{CI})$ & P-value & $\begin{array}{c}{ }^{\mathrm{a}} \mathrm{OR} \\
(95 \% \mathrm{CI}) \\
\end{array}$ & P-value \\
\hline $\mathrm{TT}^{\mathrm{R}}$ & $36(50.0 \%)$ & $\begin{array}{c}36 \\
(50.0 \%) \\
\end{array}$ & 1 & \multirow{2}{*}{0.403} & \multirow{2}{*}{$\begin{array}{c}1.95 \\
0.50-7.65\end{array}$} & \multirow{2}{*}{0.340} \\
\hline $\mathrm{GT}+\mathrm{GG}$ & $\begin{array}{c}4 \\
(36.4 \%) \\
\end{array}$ & $\begin{array}{c}7 \\
(63.6 \%) \\
\end{array}$ & $\begin{array}{c}1.75 \\
0.47-6.50 \\
\end{array}$ & & & \\
\hline $\begin{array}{l}\text { recessive } \\
\text { model }\end{array}$ & $\begin{array}{l}\text { Control } \\
(\mathrm{n}=40)\end{array}$ & $\begin{array}{c}\text { Overweight } \\
(\mathrm{n}=43)\end{array}$ & ${ }^{\mathrm{c}} \mathrm{OR}(95 \% \mathrm{CI})$ & P-value & $\begin{array}{c}{ }^{\mathrm{a}} \mathrm{OR} \\
(95 \% \mathrm{CI})\end{array}$ & P-value \\
\hline $\mathrm{GG}^{\mathrm{R}}$ & $1(50.0 \%)$ & $\begin{array}{c}1 \\
(50.0 \%) \\
\end{array}$ & 1 & \multirow{2}{*}{0.959} & \multirow{2}{*}{$\begin{array}{c}0.58 \\
0.03-10.23\end{array}$} & \multirow{2}{*}{0.712} \\
\hline $\mathrm{GT}+\mathrm{TT}$ & $39(48.1 \%)$ & $\begin{array}{c}42 \\
(51.9 \%) \\
\end{array}$ & $\begin{array}{c}1.08 \\
0.07-17.81 \\
\end{array}$ & & & \\
\hline
\end{tabular}

Reference, ${ }^{\mathrm{c} O R}$;Crude odds ratio, ${ }^{\mathrm{a}} \mathrm{OR}$; adjusted odds ratio for age CI: confidence interval 
Table 9: Association of genotypes at adiponectin polymorphism G276T with obese under co-dominant model, dominance, recessive model.

\begin{tabular}{|c|c|c|c|c|c|c|}
\hline $\begin{array}{c}\text { co dominant } \\
\text { model }\end{array}$ & $\begin{array}{c}\text { Control } \\
(n=40)\end{array}$ & $\begin{array}{l}\text { Obese } \\
(n=89)\end{array}$ & ${ }^{\mathrm{c}} \mathrm{OR}(95 \% \mathrm{CI})$ & P-value & $\begin{array}{c}{ }^{\mathrm{a}} \mathrm{OR} \\
(95 \% \mathrm{CI})\end{array}$ & $\mathrm{P}$-value \\
\hline $\mathrm{GG}^{\mathrm{R}}$ & $\begin{array}{c}4 \\
(33.3 \%) \\
\end{array}$ & $\begin{array}{c}8 \\
(66.7 \%) \\
\end{array}$ & 1 & 0.046 & 1 & 0.072 \\
\hline GT & $\begin{array}{c}2 \\
(8.0 \%) \\
\end{array}$ & $\begin{array}{c}23 \\
(92.0 \%) \\
\end{array}$ & $\begin{array}{c}5.75 \\
(0.88-37.62) \\
\end{array}$ & 0.068 & $\begin{array}{c}5.42 \\
(0.72-40.67)\end{array}$ & 0.100 \\
\hline TT & $\begin{array}{c}34 \\
(37.0 \%)\end{array}$ & $\begin{array}{c}58 \\
(63.0 \%)\end{array}$ & $\begin{array}{c}0.85 \\
(0.24-3.05)\end{array}$ & 0.806 & $\begin{array}{c}0.84 \\
(0.21-3.44)\end{array}$ & 0.810 \\
\hline dominance model & $\begin{array}{c}\text { Control } \\
(n=40)\end{array}$ & $\begin{array}{l}\text { Obese } \\
(n=89)\end{array}$ & ${ }^{c} \mathrm{OR}(95 \% \mathrm{CI})$ & P-value & $\begin{array}{c}{ }^{\mathrm{a}} \mathrm{OR} \\
(95 \% \mathrm{CI}) \\
\end{array}$ & P-value \\
\hline $\mathrm{GG}^{\mathrm{R}}$ & $\begin{array}{c}4 \\
(33.3 \%)\end{array}$ & $\begin{array}{c}8 \\
(66.7 \%)\end{array}$ & \multirow{2}{*}{$\begin{array}{c}1.13 \\
(0.32-3.98)\end{array}$} & \multirow{2}{*}{0.855} & \multirow{2}{*}{-} & \multirow[b]{2}{*}{-} \\
\hline $\mathrm{GT}+\mathrm{TT}$ & $\begin{array}{c}36 \\
(30.8 \%) \\
\end{array}$ & $\begin{array}{c}81 \\
(69.2 \%) \\
\end{array}$ & & & & \\
\hline recessive model & $\begin{array}{c}\text { Control } \\
(\mathrm{n}=40)\end{array}$ & $\begin{array}{l}\text { Obese } \\
(\mathrm{n}=89)\end{array}$ & ${ }^{c} \mathrm{OR}(95 \% \mathrm{CI})$ & P-value & $\begin{array}{c}{ }^{\mathrm{a}} \mathrm{OR} \\
(95 \% \mathrm{CI})\end{array}$ & P-value \\
\hline $\mathrm{TT}^{\mathrm{R}}$ & $\begin{array}{c}34 \\
(37.0 \%)\end{array}$ & $\begin{array}{c}58 \\
(63.0 \%) \\
\end{array}$ & \multirow{2}{*}{$\begin{array}{c}3.03 \\
(1.15-8.00)\end{array}$} & \multirow{2}{*}{0.025} & \multirow{2}{*}{$\begin{array}{c}2.91 \\
(1.01-8.41)\end{array}$} & \multirow[t]{2}{*}{0.048} \\
\hline $\mathrm{GT}+\mathrm{GG}$ & $\begin{array}{c}6 \\
(16.2 \%)\end{array}$ & $\begin{array}{c}31 \\
(83.8 \%)\end{array}$ & & & & \\
\hline
\end{tabular}

Reference, COR: Crude odds ratio, AOR;adjusted odds ratio for age CI: confidence interval

Table 10: Association of genotypes at adiponectin polymorphism T45G with obese under co-dominant model.

\begin{tabular}{|c|c|c|c|c|c|c|}
\hline $\begin{array}{c}\text { co dominant } \\
\text { model }\end{array}$ & $\begin{array}{l}\text { Control } \\
(n=40)\end{array}$ & $\begin{array}{l}\text { Obese } \\
(n=89)\end{array}$ & ${ }^{\mathrm{c}} \mathrm{OR}(95 \% \mathrm{CI})$ & P-value & $\begin{array}{c}{ }^{\mathrm{a}} \mathrm{OR} \\
(95 \% \mathrm{CI}) \\
\end{array}$ & P-value \\
\hline $\mathrm{TT}^{\mathrm{R}}$ & $\begin{array}{c}36 \\
(34.6 \%) \\
\end{array}$ & $\begin{array}{c}68 \\
(65.4 \%) \\
\end{array}$ & 1 & 0.203 & 1 & 0.128 \\
\hline GT & $\begin{array}{c}3 \\
(14.3 \%) \\
\end{array}$ & $\begin{array}{c}18 \\
(85.7 \%)\end{array}$ & $\begin{array}{c}3.18 \\
(0.88-11.51)\end{array}$ & 0.078 & $\begin{array}{c}4.11 \\
(1.03-16.50)\end{array}$ & 0.046 \\
\hline GG & $\begin{array}{c}1 \\
(25.0 \%)\end{array}$ & $\begin{array}{c}3 \\
(75.0 \%) \\
\end{array}$ & $\begin{array}{c}1.59 \\
(0.16-15.83) \\
\end{array}$ & 0.693 & $\begin{array}{c}1.94 \\
(0.13-28.06)\end{array}$ & 0.626 \\
\hline $\begin{array}{c}\text { dominance } \\
\text { model }\end{array}$ & $\begin{array}{l}\text { Control } \\
(n=40)\end{array}$ & $\begin{array}{l}\text { Obese } \\
(n=89)\end{array}$ & ${ }^{\mathrm{c}} \mathrm{OR}(95 \% \mathrm{CI})$ & P-value & $\begin{array}{c}{ }^{\mathrm{a}} \mathrm{OR} \\
(95 \% \mathrm{CI})\end{array}$ & P-value \\
\hline $\mathrm{TT}^{\mathrm{R}}$ & $\begin{array}{c}36 \\
(34.6 \%) \\
\end{array}$ & $\begin{array}{c}68 \\
(65.4 \%) \\
\end{array}$ & \multirow{2}{*}{$\begin{array}{c}2.78 \\
(0.89-8.72)\end{array}$} & \multirow[t]{2}{*}{0.080} & \multirow{2}{*}{$\begin{array}{c}3.60 \\
(1.03-12.61)\end{array}$} & \multirow[t]{2}{*}{0.045} \\
\hline $\mathrm{GT}+\mathrm{GG}$ & $4(16.0 \%)$ & $21(84.0 \%)$ & & & & \\
\hline recessive model & $\begin{array}{c}\text { Control } \\
(\mathrm{n}=40)\end{array}$ & $\begin{array}{c}\text { Obese } \\
(n=89)\end{array}$ & ${ }^{\mathrm{c}} \mathrm{OR}(95 \% \mathrm{CI})$ & P-value & $\begin{array}{c}{ }^{\mathrm{a}} \mathrm{OR} \\
(95 \% \mathrm{CI})\end{array}$ & P-value \\
\hline $\mathrm{GG}^{\mathrm{R}}$ & $\begin{array}{c}1 \\
(25.0 \%) \\
\end{array}$ & $\begin{array}{c}3 \\
(75.0 \%) \\
\end{array}$ & \multirow{2}{*}{$\begin{array}{c}0.74 \\
(0.07-7.29)\end{array}$} & \multirow[t]{2}{*}{0.793} & \multirow[t]{2}{*}{-} & \multirow[t]{2}{*}{-} \\
\hline $\mathrm{TT}+\mathrm{GG}$ & $39(31.2 \%)$ & $86(68.8 \%)$ & & & & \\
\hline
\end{tabular}

Reference, ${ }^{\mathrm{c} O R}$; Crude odds ratio, ${ }^{\mathrm{a} O R}$; adjusted odds ratio for age CI: confidence interval 
Table 11: The correlation between clinical parameters in the control group.

\begin{tabular}{|c|c|c|c|c|c|c|c|c|c|}
\hline $\begin{array}{c}\text { Normal } \\
\text { group }\end{array}$ & & BMI & Cholesterol & $\mathbf{T G}$ & HDL & LDL & VLDL & glucose & adiponectin \\
\hline \multirow{2}{*}{ BMI } & $\mathrm{r}$ & 1 & -0.007 & -0.083 & -0.007 & 0.014 & -0.09 & -0.164 & -0.256 \\
\hline & $\mathrm{P}$ & & 0.965 & 0.611 & 0.965 & 0.93 & 0.581 & 0.311 & 0.111 \\
\hline \multirow{2}{*}{ Cholesterol } & $\mathrm{r}$ & -0.007 & 1 & 0.033 & $1.000 * *$ & $.971 * *$ & 0.05 & -0.179 & -0.042 \\
\hline & $\mathrm{P}$ & 0.965 & & 0.838 & 0 & 0 & 0.758 & 0.268 & 0.795 \\
\hline \multirow{2}{*}{ TG } & $\mathrm{r}$ & -0.083 & 0.033 & 1 & 0.033 & -0.205 & $.997 * *$ & -0.098 & -0.07 \\
\hline & $\mathrm{P}$ & 0.611 & 0.838 & & 0.838 & 0.204 & 0 & 0.546 & 0.67 \\
\hline \multirow{2}{*}{ HDL } & $\mathrm{r}$ & -0.007 & $1.000 * *$ & 0.033 & 1 & $.971 * *$ & 0.05 & -0.179 & -0.042 \\
\hline & $\mathrm{P}$ & 0.965 & 0 & 0.838 & & 0 & 0.758 & 0.268 & 0.795 \\
\hline \multirow{2}{*}{ LDL } & $\mathrm{r}$ & 0.014 & $.971 * *$ & -0.205 & $.971 * *$ & 1 & -0.189 & -0.155 & -0.026 \\
\hline & $\mathrm{P}$ & 0.93 & 0 & 0.204 & 0 & & 0.242 & 0.339 & 0.872 \\
\hline \multirow{2}{*}{ VLDL } & $\mathrm{r}$ & -0.09 & 0.05 & $.997 * *$ & 0.05 & -0.189 & 1 & -0.088 & -0.065 \\
\hline & $\mathrm{P}$ & 0.581 & 0.758 & 0 & 0.758 & 0.242 & & 0.587 & 0.692 \\
\hline \multirow{2}{*}{ glucose } & $\mathrm{r}$ & -0.164 & -0.179 & -0.098 & -0.179 & -0.155 & -0.088 & 1 & -0.023 \\
\hline & $\mathrm{P}$ & 0.311 & 0.268 & 0.546 & 0.268 & 0.339 & 0.587 & & 0.889 \\
\hline \multirow{2}{*}{ adiponectin } & $\mathrm{r}$ & -0.256 & -0.042 & -0.07 & -0.042 & -0.026 & -0.065 & -0.023 & 1 \\
\hline & $\mathrm{P}$ & 0.111 & 0.795 & 0.67 & 0.795 & 0.872 & 0.692 & 0.889 & \\
\hline
\end{tabular}

* Significant correlation at level 0.05 (2-tailed).

** Significant correlation at level 0.01 (2-tailed).

Table 12: The correlation between clinical parameters in the overweight group.

\begin{tabular}{|c|c|c|c|c|c|c|c|c|c|}
\hline $\begin{array}{l}\text { Overweight } \\
\text { group }\end{array}$ & & BMI & Cholesterol & TG & HDL & LDL & VLDL & glucose & adiponectin \\
\hline \multirow[b]{2}{*}{ BMI } & $\mathrm{r}$ & \multirow[b]{2}{*}{1} & 0.082 & -0.259 & 0.082 & 0.147 & -0.261 & 0.233 & 0.022 \\
\hline & $\mathrm{P}$ & & 0.599 & 0.093 & 0.599 & 0.346 & 0.09 & 0.137 & 0.89 \\
\hline \multirow[b]{2}{*}{ Cholesterol } & $\mathrm{r}$ & 0.082 & \multirow[b]{2}{*}{1} & $.340^{*}$ & $1.000 * *$ & $.976 * *$ & $.340 *$ & 0.147 & 0.248 \\
\hline & $\mathrm{P}$ & 0.599 & & 0.026 & 0 & 0 & 0.026 & 0.352 & 0.109 \\
\hline \multirow[b]{2}{*}{ TG } & $\mathrm{r}$ & -0.259 & $.340 *$ & \multirow[b]{2}{*}{1} & $.340 *$ & 0.128 & $1.000 * *$ & -0.259 & -0.031 \\
\hline & $\mathrm{P}$ & 0.093 & 0.026 & & 0.026 & 0.413 & 0 & 0.097 & 0.845 \\
\hline \multirow[b]{2}{*}{ HDL } & $\mathrm{r}$ & 0.082 & $1.000 * *$ & $.340 *$ & \multirow[b]{2}{*}{1} & $.976^{* *}$ & $.340 *$ & 0.147 & 0.248 \\
\hline & $\mathrm{P}$ & 0.599 & 0 & 0.026 & & 0 & 0.026 & 0.352 & 0.109 \\
\hline \multirow[b]{2}{*}{ LDL } & $\mathrm{r}$ & 0.147 & $.976 * *$ & 0.128 & $.976 * *$ & & 0.128 & 0.209 & 0.268 \\
\hline & $\mathrm{P}$ & 0.346 & 0 & 0.413 & 0 & 1 & 0.413 & 0.185 & 0.082 \\
\hline \multirow[b]{2}{*}{ VLDL } & $\mathrm{r}$ & -0.261 & $.340 *$ & $\begin{array}{c}1.000 \\
* *\end{array}$ & $.340 *$ & 0.128 & \multirow[b]{2}{*}{1} & -0.261 & -0.03 \\
\hline & $\mathrm{P}$ & 0.09 & 0.026 & 0 & 0.026 & 0.413 & & 0.095 & 0.848 \\
\hline \multirow[b]{2}{*}{ glucose } & $\mathrm{r}$ & 0.233 & 0.147 & -0.259 & 0.147 & 0.209 & -0.261 & \multirow[b]{2}{*}{1} & -0.111 \\
\hline & $\mathrm{P}$ & 0.137 & 0.352 & 0.097 & 0.352 & 0.185 & 0.095 & & 0.483 \\
\hline \multirow[b]{2}{*}{ adiponectin } & $\mathrm{r}$ & 0.022 & 0.248 & -0.031 & 0.248 & 0.268 & -0.03 & -0.111 & \multirow[b]{2}{*}{1} \\
\hline & $\mathrm{P}$ & 0.89 & 0.109 & 0.845 & 0.109 & 0.082 & 0.848 & 0.483 & \\
\hline
\end{tabular}

* Significant correlation at level 0.05 (2-tailed).

** Significant correlation at level 0.01 (2-tailed). 
Table 13: The Correlation between clinical parameters in the obese group.

\begin{tabular}{|c|c|c|c|c|c|c|c|c|c|}
\hline $\begin{array}{l}\text { Obese } \\
\text { group }\end{array}$ & & BMI & $\begin{array}{c}\text { Cholestero } \\
\text { l }\end{array}$ & TG & HDL & LDL & VLDL & glucose & $\begin{array}{c}\text { adiponecti } \\
\text { n }\end{array}$ \\
\hline \multirow{2}{*}{ BMI } & $\mathrm{r}$ & 1 & 0.021 & 0.022 & 0.021 & 0.007 & 0.022 & 0.147 & $-.238 *$ \\
\hline & $\mathrm{P}$ & & 0.844 & 0.836 & 0.844 & 0.95 & 0.836 & 0.17 & 0.025 \\
\hline \multirow{2}{*}{ Cholesterol } & $\mathrm{r}$ & 0.021 & 1 & -0.02 & $1.000 * *$ & $.957 * *$ & -0.02 & $.469 * *$ & -0.086 \\
\hline & $\mathrm{P}$ & 0.844 & & 0.85 & 0 & 0 & 0.85 & 0 & 0.422 \\
\hline \multirow{2}{*}{ TG } & $\mathrm{r}$ & 0.022 & -0.02 & 1 & -0.02 & $-.306^{* *}$ & $1.000 * *$ & -0.052 & -0.046 \\
\hline & $\mathrm{P}$ & 0.836 & 0.85 & & 0.85 & 0.004 & 0 & 0.628 & 0.668 \\
\hline \multirow{2}{*}{ HDL } & $\mathrm{r}$ & 0.021 & $1.000 * *$ & -0.02 & 1 & $.957 * *$ & -0.02 & $.469 * *$ & -0.086 \\
\hline & $\mathrm{P}$ & 0.844 & 0 & 0.85 & & 0 & 0.85 & 0 & 0.422 \\
\hline \multirow[t]{2}{*}{ LDL } & $\mathrm{r}$ & 0.007 & $.957 * *$ &. & $.957 * *$ & 1 & $-.306 * *$ & $.460 * *$ & -0.067 \\
\hline & $\mathrm{P}$ & 0.95 & 0 & 0.004 & 0 & & 0.004 & 0 & 0.534 \\
\hline \multirow{2}{*}{ VLDL } & $\mathrm{r}$ & 0.022 & -0.02 & $\begin{array}{c}1.000^{*} \\
*\end{array}$ & -0.02 & $-.306 * *$ & 1 & -0.052 & -0.046 \\
\hline & $\mathrm{P}$ & 0.836 & 0.85 & 0 & 0.85 & 0.004 & & 0.628 & 0.667 \\
\hline \multirow{2}{*}{ glucose } & $\mathrm{r}$ & 0.147 & $.469 * *$ & -0.052 & $.469 * *$ & $.460 * *$ & -0.052 & 1 & -0.031 \\
\hline & $\mathrm{P}$ & 0.17 & 0 & 0.628 & 0 & 0 & 0.628 & & 0.773 \\
\hline \multirow{2}{*}{ adiponectin } & $\mathrm{r}$ & $-.238 *$ & -0.086 & -0.046 & -0.086 & -0.067 & -0.046 & -0.031 & 1 \\
\hline & $\mathrm{P}$ & 0.025 & 0.422 & 0.668 & 0.422 & 0.534 & 0.667 & 0.773 & \\
\hline
\end{tabular}

* Significant correlation at level 0.05 (2-tailed).

** Significant correlation at level 0.01 (2-tailed). 